\title{
Spatio-temporal heterogeneity of soil microbial properties in a conventionally managed arable field
}

\author{
Anna Piotrowska-Długosz ${ }^{1}$ - Barbara Breza-Boruta ${ }^{2}$. Jacek Długosz ${ }^{1}$ \\ Received: 24 January 2016 / Accepted: 3 May 2018 / Published online: 11 May 2018 \\ (C) The Author(s) 2018
}

\begin{abstract}
Purpose Knowledge about the spatio-temporal variability of soil microbial properties is crucial in evaluating their structurefunction relationship and their impact on ecosystem functions. The aim of the study was to determine the spatio-temporal variation of the selected microbial properties at the surface horizon in a conventionally managed arable field.

Materials and methods The area selected for the research, which was mainly covered with typical Luvisols, was a uniformly managed system that was considered to be homogenous in respect to texture (mostly loamy fine sand). Winter wheat was cultivated after winter rape as the forecrop. A grid soil sampling $(10 \mathrm{~m} \times 10 \mathrm{~m})$ was used to assess the spatial heterogeneity of soil properties across a 0.5 -ha field. Soil samples were collected at 50 points from the upper $20 \mathrm{~cm}$ of soil in April and August 2007. Colony-forming units (CFUs) of bacteria, fungi and actinomycetes, and basal respiration (BR) were analyzed. Data were evaluated using classical statistical and geostatistical methods.

Results and discussion Fungal CFUs were significantly lower than the bacterial ones with a B/F (bacteria/fungi) ratio of 80.0 in April and 45.1 in August. Bacterial CFUs, B/F ratio, and BR level revealed significantly higher values in April than in August, while fungi showed the opposite trend. Other studied properties did not show significant differences between sampling months. Only some of the properties, such as the bacterial community in August, the number of actinomycetes in April, and $q \mathrm{CO}_{2}$ on both sampling dates, revealed significant spatial autocorrelation (Moran's $I$ ) and were spatially dependent at the scale of sampling grid, whereas the $q \mathrm{CO}_{2}$ revealed a higher differentiation in the spatial pattern between April and August than the other studied properties. Most of the spatially correlated properties were in the weak variability class (a nugget effect $>75 \%$ ), while only the $q \mathrm{CO}_{2}$ (August) ratio was in the moderate variability class (a nugget effect between 25 and $75 \%$ ).

Conclusions Most of the microbial-related properties did not exhibit a spatial structure at the examined scale, thus suggesting that changes in these properties would be detectable at a distance shorter than $10 \mathrm{~m}$. More frequent seasonal sampling must be included in the sampling strategy in order to better understand whether studied properties show any permanent spatial patterns in soil over time or whether they are more randomized.
\end{abstract}

Keywords Geostatistics $\cdot$ Microbial colony-forming units $\cdot$ Microorganisms $\cdot$ Soil respiration $\cdot$ Spatial variability

Responsible editor: Richard K. Shaw

Anna Piotrowska-Dhugosz

ap03@wp.pl

1 Department of Biogeochemistry and Soil Science, Laboratory of Soil Science and Biochemistry, Faculty of Agriculture and Biotechnology, UTP University of Science and Technology, 6 Bernardyńska St., 85-029 Bydgoszcz, Poland

2 Department of Microbiology and Food Technology, Faculty of Agriculture and Biotechnology, UTP University of Science and Technology, 6 Bernardyńska St., 85-029 Bydgoszcz, Poland

\section{Introduction}

Soil microorganisms are the living components of soil organic matter, and despite comprising only a small percentage of the total mass of organic matter, they are considered to have a crucial impact on numerous important biochemical processes such as the release of plant-available nutrients, organic matter dynamics, and soil structure formation (Gangneux et al. 2011).

Soil is a very heterogeneous and complex system in which neither microorganisms nor other soil components are irregularly distributed (Černohlávková 2009). Even within uniformly managed systems, which are typically assumed to be more 
homogenous than natural systems, biological processes (e.g., growth and colony formation) may produce aggregations of microorganisms at various spatial scales (Franklin and Mills 2003). Soil microorganisms and microbial processes are controlled by factors such as organic matter content, soil moisture, texture, and $\mathrm{pH}$, all of which exhibit spatial heterogeneity as well (Guox et al. 2012). Studies of the spatial patterns in microbial communities are still relatively rare (Martiny et al. 2011), and determining their spatial patterns is extremely complicated due to the large number of factors that affect microbial activity (Yergeau et al. 2010) as well as the fact that microbial properties have considerable temporal variability (Lauber et al. 2013). Soil microbiota can exhibit patchy distributions at a scale from several millimeters to several meters (Nunan et al. 2003; Tecon and Or 2017). The spatial variability is often determined for one scale (e.g., Peigné et al. 2009), but multi-scaled comparisons have been considered as well (e.g., Franklin and Mills 2009). Franklin and Mills (2003) had previously explored the multi-scale spatial distribution of microbial community structure in an agricultural field and found that several scales of spatial autocorrelation can exist within the centimeter to $10-\mathrm{m}$ scale.

Most studies of microbial and other soil properties are focused on the differences in their spatial structure that are caused by natural and anthropogenic factors. It was shown that the spatial distribution of soil microorganisms depends on the position in landscape (Du et al. 2015), type of land use (e.g., forest vs. cultivated field) (Francioli et al. 2014), time and methods of soil sampling, and soil treatment (e.g., different types of tillage, fertilization, or crop rotation) (Garcia-Orenes et al. 2013).

Less attention has been paid to the spatial variation of soil properties in a uniformly managed arable field, where no experimental factors were tested (Peigné et al. 2009; Franklin and Mills 2009). Very often, the soils within uniformly managed sites are considered to be homogenous, and thus, it is assumed that the soil properties are similar. Accordingly, the number of analyses of soil properties is limited to a few measured points in given area, and a composite sample is often assessed to represent the average population in the area sampled. However, the average values of homogenized soil samples often do not accurately reflect the real state of soil ecosystems.

High spatial heterogeneity of soil properties, especially microbial ones, can mask the effects of different soil management treatments (Peigné et al. 2009). It is, therefore, important to detect, and ultimately estimate and map the spatial patterns of soil properties. Spatial variability and the dependence of soil properties are controlled by inherent variations in soil characteristics (e.g., parental material, vegetation, and climate) or are affected by exogenous factors such as crop production practices (tillage, fertilization, and crop rotation) (Gülser et al. 2016). Such practices may alter the local patchiness of soil nutrients and contribute to the additional heterogeneity of soil properties and thus affect soil microbial communities (Cavigelli et al. 2005).

Conventional statistical analyses are not appropriate to identify spatial patterns as these analyses require an assumption of independence among samples, which is violated when autocorrelated (spatially dependent) data are considered (Deblauwe et al. 2012). Thus, since the 1950s, spatial statistics have been developed to deal with the problem of spatial autocorrelation (Cobo et al. 2010). One of the most widely used approaches for evaluating the spatial variability of natural resources such as soils is geostatistics (Jafari et al. 2011). The geostatistical methods primarily consider the spatial variability of soil properties as a random process that is dependent on space but there has been an increasing need to estimate temporal changes in the spatial patterns of such properties as well (Shahandeh et al. 2005; Liu et al. 2009). The application of geostatistical methods by soil scientists focuses on predicting the spatial variability of soil properties using different kriging methods over small to large spatial scales (Peigné et al. 2009; Wang et al. 2009; Baldrian et al. 2010a).

Current studies on the temporal variability in microbial properties have shown contradictory trends with various studies reporting peaks in different seasons as well as both positive and negative responses to temporal patterns in soil temperature and moisture (Borowik and Wyszkowska 2016; Bao et al. 2016). The composition of bacterial and fungal communities can vary on the scale of days (Zhang et al. 2011), seasons (Kennedy et al. 2006; Lipson 2007), and years (DeBruyn et al. 2011). In some cases, the changes in these communities can be linked to changes in the soil environmental conditions (Rasche et al. 2011). Studies from temperate ecosystems found temperature to be important in determining temporal variability (Wardle 1998), while in a tropical forest, the highest microbial biomass was usually observed when soil moisture was favorable (Pandey et al. 2007).

Taking into account the significant temporal variability of the soil biological properties, we hypothesized that these properties differed in spatial distribution over time in the same area, which may be helpful for addressing basic scientific questions, such as what is the nature of the spatial distribution of microorganisms and whether the spatial pattern of soil microbial properties is time dependent and if so to what extent. Therefore, the aims of this study were to (1) investigate the spatial variation of microbial properties in the surface horizons of Luvisols and the contribution of random variability (nugget) to total variability ( sill) of studied properties, (2) determine whether temporal variability affects the spatial pattern variation of microbial properties, and (3) assess the relationship between the set of soil microbial features and some physicochemical properties across the studied area. 


\section{Material and methods}

\subsection{Site description and sample collection}

The study was carried out in a grid patterned $40 \times 90 \mathrm{~m}$ area in 80 ha of an agricultural field located near the village of Orlinek (near Mrocza) in the Pomerania and Cuiavia region $\left(53^{\circ} 15^{\prime} 31^{\prime \prime} \mathrm{N}, 17^{\circ} 32^{\prime} 43^{\prime \prime} \mathrm{E}\right)$, northwest Poland. The field has been continuously managed for more than 20 years. The soil that was studied was classified as a typical Luvisol (IUSS Working Group WRB 2007), which was composed of $79.3 \%$ sand, $14.6 \%$ silt, and $6.1 \%$ clay. The landform of the study area is flat. Winter wheat (Triticum aestivum L.) was cultivated after winter rape (Brassica napus L.) as the forecrop. Mineral fertilization was applied in accordance with winter wheat requirements and presented in details earlier (PiotrowskaDługosz et al. 2017). The area was characterized by an average monthly air temperature of $12.9^{\circ} \mathrm{C}$ and the total rainfall of $447.4 \mathrm{~mm}$ during the growing season (MarchOctober) in 2007 (Table 1). Soil samples (50) were collected from the $0-20-\mathrm{cm}$ top layer of soil at regular intervals $(10 \mathrm{~m} \times 10 \mathrm{~m})$ during the stage of winter wheat spreading on April 12, 2007 and directly after the harvest on August 6, 2007. Each composite sample comprised ten sub-samples that were taken randomly from a circular area with a radius of $2 \mathrm{~m}$ from the node point (ISO 10381-2: 2002), mixed to account for short-range (< $10 \mathrm{~m})$ spatial variability.

The soil samples were transported to the laboratory in sterile plastic bags and were stored at $4{ }^{\circ} \mathrm{C}$ (up to $24 \mathrm{~h}$ ) to estimate the number of aerobic heterotrophic bacteria, filamentous fungi, and actinomycetes as well as the soil respiration rate.

Table 1 Distribution of monthly averaged air temperature and monthly sum of rainfall in 2007

\begin{tabular}{lll}
\hline Months & Temperature $\left({ }^{\circ} \mathrm{C}\right)$ & Rainfall $(\mathrm{mm})$ \\
\hline January & 3.4 & 73 \\
February & -0.8 & 33 \\
March & 5.5 & 55 \\
April & 9.0 & 17 \\
May & 14.3 & 84 \\
June & 18.2 & 112 \\
July & 18.0 & 89 \\
August & 18.1 & 29 \\
September & 12.7 & 40 \\
October & 7.2 & 23 \\
November & 1.7 & 27 \\
December & 0.8 & 36 \\
\hline
\end{tabular}

\subsection{Soil biological properties}

The plate count method was employed to estimate the number of aerobic heterotrophic bacteria, filamentous fungi, and actinomycetes. Microbiological inoculation was done during $24 \mathrm{~h}$ after sample collection. Ten grams of each soil sample was added to $90 \mathrm{ml}$ of Ringer's solution. After homogenization for $30 \mathrm{~min}$, tenfold serial dilutions were made $\left(10^{-1}\right.$ to $\left.10^{-6}\right)$. Then, inoculations of the prepared soil solutions were made on proper culture media. In order to determine the total number of bacteria, a yeast extract-peptone-soil extract medium was used (YPS) (Atlas 1997). Actinomycetes were isolated on yeast extract glucose agar (YGA) with $100 \mu \mathrm{g} \mathrm{ml}^{-1}$ nystatin and filamentous fungi were isolated on Rose-Bengal agar containing $30 \mu \mathrm{g} \mathrm{ml}^{-1}$ streptomycin (Atlas 1997). The number of colony-forming units (CFUs) that was obtained was determined per $1 \mathrm{~g}$ of soil dry matter (CFUs g ${ }^{-1}$ d.m. of soil).

Basal respiration (BR) was determined according to Stotzky (Stotzky 1965) with some modification (Piotrowska et al. 2006). The rate of BR was expressed in milligrams $/ \mathrm{CO}_{2}-$ $\mathrm{C} /$ kilogram of soil per hour within 15 days of incubation (sum of five individual measurements). The specific respiration of the microbial biomass or the microbial metabolic quotient was calculated as the ratio of BR to microbial biomass: $q \mathrm{CO}_{2}$ $\left(\mu \mathrm{CO}_{2}-\mathrm{C} / \mathrm{mg} \mathrm{MBC}\right.$ per hour) (Anderson and Domsch 1990). The data about soil microbial properties are reported as averages of fourfold laboratory determinations.

\subsection{Statistical and geostatistical approaches}

The dataset was analyzed independently twice- - first in a classical way in order to investigate the general status of the soil microbiological properties at two sampling times and their links with the physicochemical soil properties and then using a geostatistics approach in order to investigate the spatial variation of soil properties. The basic statistical parameters were evaluated using STATISTICA v. 9.0 Software. Normality was the general observation for only some variables (Shapiro-Wilk test). Most of the properties did not show a normal distribution and therefore were transformed accordingly (Table 2). Since the transformation improved the normality of most of the properties, further analyses were performed with the corrected data. Differences in the average values of the soil properties collected in April and August were determined using Tukey's test (significant level $=p<0.05$ ). Linear correlation analysis based on Pearson's coefficients $(p<0.05)$ was performed to determine the relationships between the variables. A classification scheme based on their CV [\%] was used to identify the extent of variability for the soil properties (Wilding 1985).

The spatial relationship among neighboring observations of the variables were assessed using the global Moran's $I$ autocorrelation coefficient (Liu et al. 2013). The spatial autocorrelation is a measure of the similarity (correlation) between 
Table $2 \quad p$ values and statistical transformations of soil properties

\begin{tabular}{llll}
\hline Property & Sampling month & $p$ value & Transformation \\
\hline Bacterial CFUs $\left(\times 10^{6}\right)$ & April & 0.0000 & Log \\
& August & 0.0000 & Log \\
Fungal CFUs $\left(\times 10^{5}\right)$ & April & 0.4017 & - \\
& August & 0.8354 & - \\
Actinomycetes CFUs & April & 0.0003 & Log \\
$\left(\times 10^{5}\right)$ & August & 0.0019 & Log \\
$\mathrm{B} / \mathrm{F}$ & April & 0.0000 & \\
& August & 0.0000 & \\
$\mathrm{BR}\left(\mathrm{mg} \mathrm{CO}_{2} \cdot \mathrm{kg}^{-1} \mathrm{~h}^{-1}\right)$ & April & 0.0090 & Log \\
& August & 0.0077 & Sqrt \\
$q \mathrm{CO}_{2}$ & April & 0.0002 & Log \\
& August & 0.0944 & - \\
\hline
\end{tabular}

$\mathrm{B} / \mathrm{F}$ bacteria to fungi ratio, $\mathrm{BR}$ basal respiration, $q \mathrm{CO}_{2}$ metabolic quotient, Log logarithmic transformation, Sqrt square root transformation

nearby observations of a single variable on a two-dimensional surface. The pairs of observation of a single variable that are close to each other are more similar, and pairs of observations of variables that are far apart from each other are more likely to be less similar (Griffith and Chun 2016). The values of Moran's $I$ range from +1.0 (strong positive spatial autocorrelation) to 0 (no autocorrelation, a random pattern) and to -1.0 (strong negative autocorrelation). Moran's $I$ was calculated using a 50-m active lag distance and a $10-\mathrm{m}$ lag interval (ArcGIS 9.3).

A semivariograms were determined for soil properties that were studied in order to characterize the degree of spatial variability between neighboring samples, and the appropriate model function was fitted to the semivariogram (Webser and Oliver 2008). Depending on the spatial characteristics described by the data, spherical, linear, and Bassel-K models were fitted to different variables. The parameters of the model describing the spatial structure $\left(\gamma(h)=\mathrm{C}_{\mathrm{o}}+\mathrm{C}\right)$ such as nugget semivariance, range, and sill or total semivariance were calculated. $\mathrm{C}_{\mathrm{o}}$ represents the nugget effect, which is the variance at zero distance and represents field and experimental variability or random variability, which is undetectable at the sampling scale. The sill $\left(\mathrm{C}_{\mathrm{o}}+\mathrm{C}\right)$ is the lag distance between the measurements at which one value for a variable does not influence the neighboring values. The range is the separation distance at which the values of one variable become spatially independent of another. At separation distances greater than the range, the sampled points are no longer spatially correlated (Shahandeh et al. 2005). Furthermore, the ratio of the nugget to sill $[\mathrm{Co} /(\mathrm{Co}+\mathrm{C})] \cdot 100$ indicates the degree of randomness in the data's spatial variability (Cambardella et al. 1994). This ratio was used in this study to define three classes of spatial dependence for the soil variables. When the ratio was less than $25 \%$, the variable was considered to have a strong dependence; when it was between 25 and $75 \%$, the soil variable had a moderate spatial dependence; and if the ratio was higher than $75 \%$ or the slope of the semivariogram was $=0$, the variable was considered to be random or a non-spatially correlated (pure nugget).

To choose the best models to adjust the empirical variograms, a cross-validation procedure was applied. The criterion for selecting the best fitting models was the mean squared deviation ratio (MSDR), which was calculated from the squared errors and kriging variances (Bishop and Lark 2006). If the model for the variogram is accurate, the MSDR should be close to one (Kerry and Oliver 2007). The punctual kriging was the procedure by which the values of the soil properties were estimated at unsampled locations (Webser and Oliver 2008). The maps illustrating the spatial variance of the parameters that were determined were drawn based on the semivariograms. The geostatistical calculations were done using Isatis software (Geovariance Co.).

\section{Results}

\subsection{Descriptive statistics and correlation analysis of soil properties}

The dataset of the basic properties of the soil under study (e.g., $\mathrm{pH}$, soil moisture, total $\mathrm{C}$ and $\mathrm{N}$, clay, silt, and sand fractions) was presented earlier (Piotrowska and Dlugosz 2012).

Only fungal CFUs in April and $q \mathrm{CO}_{2}$ ratio in August were normally distributed in the studied soil. The other properties were not distributed normally and an appropriate transformation was done before further geostatistical analysis (Table 2). Although a logarithmic transformation of $\mathrm{B} / \mathrm{F}$ ratio values reduced its skewness, the values were still not normally distributed. A normal distribution of soil properties was confirmed by the similar values of means and medians as well as by skewness coefficients that were close to 0 (between 0.13 and 0.59) (Table 3). A left-tailed skewness resulted in the mean being lower than the median and more results were higher than the mean, which was mainly true for the total bacteria count and the $\mathrm{B} / \mathrm{F}$ ratio. A positive kurtosis indicates a relatively peaked distribution whereas a negative one indicates a flat distribution compared to the normal distribution. Fungal CFUs showed kurtosis values not much higher than zero, while the total count of bacteria and the $\mathrm{B} / \mathrm{F}$ ratio data both in April and August as well as the $q \mathrm{CO}_{2}$ results in April indicated a high leptokurtic distribution.

The coefficient of variation (CV\%) was calculated as an index for assessing the overall variability of the dataset (Wilding 1985). Most of the studied variables revealed a high variability $(\mathrm{CV}>35 \%)$, which indicated that the results were quite differentiated on the studied area. Among these properties, the total bacteria count and the $\mathrm{B} / \mathrm{F}$ ratio from both 
Table 3 Statistics of soil microbial properties $(n=50)$

\begin{tabular}{|c|c|c|c|c|c|c|c|c|c|c|}
\hline Property & Sampling month & Min & Max & Mean & Geometric mean & Median & SD & Skewness & Kurtosis & $\mathrm{CV}(\%)$ \\
\hline \multirow[t]{2}{*}{ Bacterial CFUs $\left(\times 10^{6}\right)$} & April & 11.0 & 141.0 & $36.0 \mathrm{a}$ & 30.0 & 28.0 & 26.0 & 2.34 & 6.54 & 72.0 \\
\hline & August & 6.0 & 77.0 & $23.9 b$ & 20.5 & 19.2 & 15.0 & 1.88 & 3.63 & 62.8 \\
\hline \multirow[t]{2}{*}{ Fungal CFUs $\left(\times 10^{5}\right)$} & April & 1.4 & 9.4 & $4.5 b$ & 4.2 & 4.4 & 1.7 & 0.44 & 0.29 & 38.7 \\
\hline & August & 1.0 & 9.3 & $5.3 \mathrm{a}$ & 5.0 & 5.0 & 1.8 & 0.13 & 0.12 & 33.3 \\
\hline \multirow[t]{2}{*}{ Actinomycetes CFUs $\left(\times 10^{5}\right)$} & April & 2.5 & 28.6 & $11.4 \mathrm{a}$ & 10.2 & 10.5 & 5.7 & 1.27 & 1.61 & 49.6 \\
\hline & August & 3.2 & 33.8 & $13.7 \mathrm{a}$ & 12.2 & 12.7 & 6.7 & 1.15 & 1.44 & 49.2 \\
\hline \multirow[t]{2}{*}{$\mathrm{B} / \mathrm{F}$ ratio } & April & 78.6 & 150 & $80.0 \mathrm{a}$ & 71.4 & 63.6 & 152.9 & 2.84 & 9.02 & 110 \\
\hline & August & 60.0 & 82,8 & $45.1 \mathrm{~b}$ & 41.0 & 38.4 & 83.3 & 3.21 & 12.2 & 86.7 \\
\hline \multirow[t]{2}{*}{$\mathrm{BR}\left(\mathrm{mg} \mathrm{CO} \mathrm{CO}_{2} \cdot \mathrm{kg}^{-1} \mathrm{~h}^{-1}\right)$} & April & 0.53 & 1.58 & $0.93 \mathrm{a}$ & 0.91 & 0.92 & 0.23 & 0.69 & 0.82 & 24.9 \\
\hline & August & 0.28 & 1.17 & $0.69 b$ & 0.67 & 0.66 & 0.18 & 0.72 & 1.01 & 25.8 \\
\hline \multirow[t]{2}{*}{$q \mathrm{CO}_{2}$ ratio } & April & 0.17 & 1.01 & $0.38 \mathrm{a}$ & 0.35 & 0.35 & 0.18 & 1.32 & 2.14 & 45.9 \\
\hline & August & 0.05 & 0.75 & $0.32 \mathrm{a}$ & 0.27 & 0.29 & 0.16 & 0.59 & -0.17 & 50.8 \\
\hline
\end{tabular}

Different small letters between April and August indicate significant differences (Tukey's test, $p<0.05$ ); The abbreviations of each variable are those given in Table 2

$S D$ standard deviation; $C V(\%)$ coefficient of variation

sampling dates tended to be the most variable with a $\mathrm{CV}$ value that ranged from 62.8 to $110 \%$ (Table 3 ). Only soil respiration showed a moderate variability as was indicated by $\mathrm{CV}$ values of between 24.9 and $25.8 \%$.

The significant correlation coefficients obtained among the studied properties and chemical properties showed earlier (Piotrowska and Długosz 2012) are presented in Table 4 $(p<0.05)$. A significant but relatively weak relationship was found between bacterial CTUs and $\mathrm{pH}_{2} \mathrm{O}$ in both April and August. A significant but negative relationship was found between fungal CTUs and $\mathrm{pH} \mathrm{H}_{2} \mathrm{O}$ on both sampling dates. The organic carbon content was positively correlated with BR, and fungal CTUs in both April and August.

\subsection{Geostatistical analysis of properties studied}

Spatial autocorrelation of soil properties was calculated from grid points at $10-\mathrm{m}$ lag intervals. Significant spatial autocorrelation was only found for bacterial CFUs in August, actinomycetes count in April, and $q \mathrm{CO}_{2}$ ratio on both sampling

Table 4 Correlation matrix

\begin{tabular}{|c|c|c|}
\hline \multirow[t]{2}{*}{ Relationship } & \multicolumn{2}{|c|}{ Coefficient of correlation } \\
\hline & April & August \\
\hline Bacterial CFUs/pH $\mathrm{H}_{2} \mathrm{O}$ & 0.483 & 0.423 \\
\hline Fungal CFUs/pH $\mathrm{H}_{2} \mathrm{O}$ & -0.424 & -0.465 \\
\hline $\mathrm{C}_{\mathrm{ORG}} / \mathrm{BR}$ & 0.328 & 0.452 \\
\hline $\mathrm{C}_{\mathrm{ORG}} /$ fungal CFUs & 0.326 & 0.415 \\
\hline
\end{tabular}

Correlations presented are significant at $p<0.05$

$C_{O R G}$ organic carbon, $B R$ basal respiration dates. (Table 5). The spatial autocorrelation was low ranging from 0.158 to 0.097 . The highest value of Moran's $I$ was noted for the $q \mathrm{CO}_{2}$ ratio determined in August (0.158).

To characterize the spatial variability of the properties, spatially autocorrelated linear (L) or spherical (Sph) models with the nugget effect (NE) were fitted to the calculated semivariograms (Table 6, Fig. 1a-c). The results indicated that most of the heterogeneity of soil properties was due to the random variability. The spatial heterogeneity of the variables studied was categorized into two classes based on the percentage of total variance (sill) present as a random variance $[(\mathrm{Co} / \mathrm{Co}+\mathrm{C}), \%]$. Most of the variables showed a weak spatial dependence and had a nugget/sill ratio over $75 \%$, and only soil moisture and $q \mathrm{CO}_{2}$ in August revealed a moderate spatial structure. The $q \mathrm{CO}_{2}$ ratio showed a higher differentiation in the spatial pattern than the other properties studied between April and August (Table 6). Variables such as total fungi count and BR level showed a pure nugget effect (a nugget $/$ sill ratio $=100 \%)$ (Fig. 1c).

The ranges of influence, which ranged between 40 and $50 \mathrm{~m}$ (Table 6), were only calculated for the $q \mathrm{CO}_{2}$ ratio since it was characterized by a spherical model of the semivariogram. The range values were not, however, calculated for the total bacteria and the actinomycetes count despite the fact that they were spatially dependent at the scale of our sampling grid, because the linear model was fitted to the calculated semivariograms of these properties.

\subsection{Temporal changes of data and their spatial patterns}

Significant differences between the properties that were studied in April and August were observed only for the bacterial and fungal CFUs, the B/F ratio, and soil respiration (Tukey's 
Table 5 Moran's $I$ for properties studied

\begin{tabular}{lllll}
\hline Property & Sampling month & Moran's $I$ & $Z$ Score & $p$ value \\
\hline Bacterial CFUs $\left(\times 10^{6}\right)$ & April & 0.046 & 1.472 & 0.142 \\
& August & 0.106 & 2.731 & 0.006 \\
Fungal CFUs $\left(\times 10^{5}\right)$ & April & -0.018 & 0.044 & 0.965 \\
& August & 0.026 & 0.967 & 0.334 \\
Actinomycetes CFUs $\left(\times 10^{5}\right)$ & April & 0.103 & 2.602 & 0.009 \\
& August & 0.038 & 1.226 & 0.221 \\
$\mathrm{~B} / \mathrm{F}$ ratio & April & 0.050 & 1.607 & 0.108 \\
& August & 0.032 & 1.233 & 0.218 \\
$\mathrm{BR}\left(\mathrm{mg} \mathrm{CO}{ }^{2} \mathrm{~kg}^{-1} \mathrm{~h}^{-1}\right)$ & April & 0.011 & 0.651 & 0.515 \\
& August & -0.097 & -1.613 & 0.107 \\
$q \mathrm{CO} 2$ & April & 0.098 & 2.521 & 0.012 \\
& August & 0.158 & 3.709 & 0.0002 \\
\hline
\end{tabular}

The abbreviations of each variable are those given in Table 2 test, $p<0.05$, Table 3 ). Based on the mean values, both bacterial CFUs and the $\mathrm{B} / \mathrm{F}$ ratio and soil basal respiration were higher in April than in August (43, 44, and 26\%, respectively), while fungal CFUs were significantly higher in August compared to April (15\%).

The main application of geostatistics to soil science has been to estimate and map the soil property values that could occur in unsampled areas. The spatial pattern of the spatially autocorrelated properties are shown in Fig. 2a-d. The kriged maps of bacterial CFUs differed on both sampling dates (Fig. 2a, b). The highest bacterial CFUs in April were observed along the western part of the transect at a length of 0 to $10 \mathrm{~m}$ and over the entire width of the area. The lowest count of bacteria was distributed in the eastern part of the field ( 65 to $90 \mathrm{~m}$ long) and over the entire width of the area). The distribution of bacterial CFUs in August was different. The lowest count of bacteria in August was noted in the northwest quadrant of the field ( 0 to $20 \mathrm{~m}$ long and 20 to $40 \mathrm{~m}$ wide), while the highest was observed in an area 50 to $90 \mathrm{~m}$ long and over the entire width of the area. The spatial distribution of the actinomycetes CFUs was different than those of the bacteria and did not share any similarities at both sampling times. In April, a higher count of actinomycetes tended to be located at lengths of 0 to $60 \mathrm{~m}$ and 15 to $40 \mathrm{~m}$ wide. A band of relatively lower actinomycetes CFUs ran vertically from the north to the south of the field at a length of 60 to $90 \mathrm{~m}$ (Fig. 2c). In August, the actinomycete count was uniformly distributed within the area, and only small area between 30 and $70 \mathrm{~m}$ long and 0 to $15 \mathrm{~m}$ wide had lower values of this property (Fig. 2d). Similarly, other properties showed different spatial structures depending on the sampling time (data not presented).

\section{Discussion}

\subsection{Basic statistics of studied variables and their seasonal changes}

The data of the properties that were measured appeared to be variable within one sampling time as well as between both

Table 6 Parameters of variogram models

\begin{tabular}{|c|c|c|c|c|c|c|c|c|c|}
\hline Property & Sampling month & Model & $\begin{array}{l}\text { Nugget } \\
\text { (Co) }\end{array}$ & $\begin{array}{l}\text { Sill } \\
(\mathrm{Co}+\mathrm{C})\end{array}$ & $\begin{array}{l}\mathrm{Co} /(\mathrm{Co}+\mathrm{C}) \\
(\%)\end{array}$ & $\begin{array}{l}\text { Range } \\
(\mathrm{m})\end{array}$ & SE & MSDR & SD \\
\hline Bacterial CFUs & $\begin{array}{l}\text { April } \\
\text { August }\end{array}$ & $\begin{array}{l}\mathrm{L}, \mathrm{NE} \\
\mathrm{L}, \mathrm{NE}\end{array}$ & $\begin{array}{l}0.044 \\
0.030\end{array}$ & $\begin{array}{l}0.0485 \\
0.0334\end{array}$ & $\begin{array}{l}90.7 \\
90.0\end{array}$ & - & $\begin{array}{l}-0.040 \\
0.005\end{array}$ & $\begin{array}{l}1.076 \\
1.277\end{array}$ & $\begin{array}{l}\text { W } \\
\text { W }\end{array}$ \\
\hline Fungal CFUs & August & $\mathrm{NE}$ & $3.63 \cdot 10^{8}$ & - & 100 & - & 0.090 & 0.978 & $\mathrm{~W}$ \\
\hline Actinomycetes CFUs & $\begin{array}{l}\text { April } \\
\text { August }\end{array}$ & $\begin{array}{l}\text { L, NE } \\
\text { L, NE }\end{array}$ & $\begin{array}{l}0.036 \\
0.036\end{array}$ & $\begin{array}{l}0.0384 \\
0.0390\end{array}$ & $\begin{array}{l}93.7 \\
92.3\end{array}$ & - & $\begin{array}{l}-0.029 \\
0.021\end{array}$ & $\begin{array}{l}0.992 \\
1.077\end{array}$ & $\begin{array}{l}\text { W } \\
\text { W }\end{array}$ \\
\hline $\mathrm{BR}\left(\mathrm{mg} \mathrm{CO} \mathrm{CO}_{2} \cdot \mathrm{kg}^{-1} \mathrm{~h}^{-1}\right)$ & $\begin{array}{l}\text { April } \\
\text { August }\end{array}$ & $\begin{array}{l}\mathrm{NE} \\
\mathrm{NE}\end{array}$ & $\begin{array}{l}0.011 \\
0.011\end{array}$ & $\begin{array}{l}0.011 \\
0.011\end{array}$ & $\begin{array}{l}100 \\
100\end{array}$ & - & $\begin{array}{l}0.0457 \\
0.0589\end{array}$ & $\begin{array}{l}0.987 \\
1.079\end{array}$ & $\begin{array}{l}\text { W } \\
\text { W }\end{array}$ \\
\hline$q \mathrm{CO} 2$ & $\begin{array}{l}\text { April } \\
\text { August }\end{array}$ & $\begin{array}{l}\text { Sph, NE } \\
\text { Sph, NE }\end{array}$ & $\begin{array}{l}0.0336 \\
0.0284\end{array}$ & $\begin{array}{l}0.028 \\
0.012\end{array}$ & $\begin{array}{l}83.3 \\
42.2\end{array}$ & $\begin{array}{l}40 \\
50\end{array}$ & $\begin{array}{l}0.0303 \\
-0.0260\end{array}$ & $\begin{array}{l}0.992 \\
1.041\end{array}$ & $\begin{array}{l}\mathrm{W} \\
\mathrm{M}\end{array}$ \\
\hline
\end{tabular}

The abbreviations of each variable are those given in Table 2

$S p h$ spherical, $L$ linear, $N E$ nugget effect, $S E$ standard error, $M S D R$ mean squared deviation ratio, $S D$ spatial dependence, $M$ moderate, $W$ weak 
Fig. 1 Experimental semivariograms of (a) $q \mathrm{CO}_{2}$ in April, (b) $q \mathrm{CO}_{2}$ in August, (c) BR in April a)

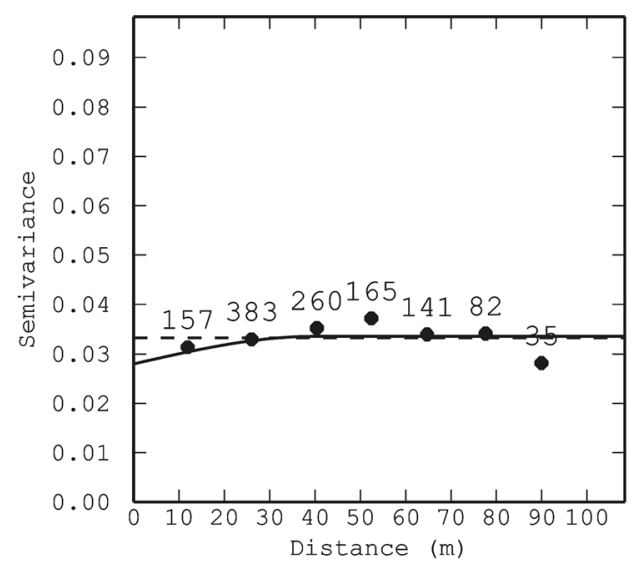

b)

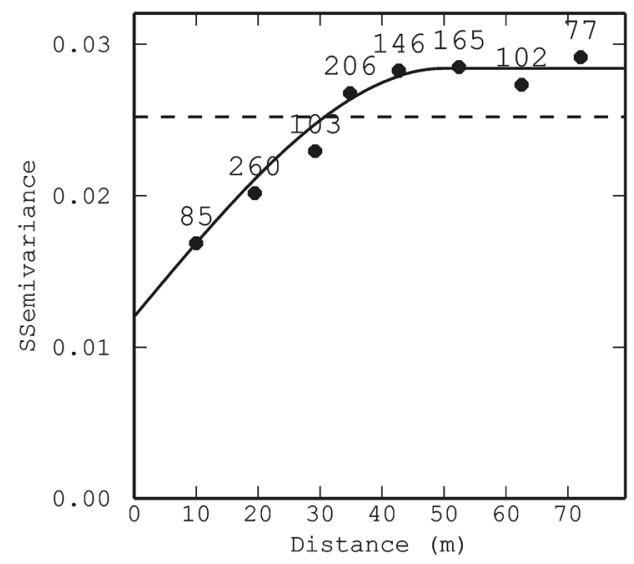

c)

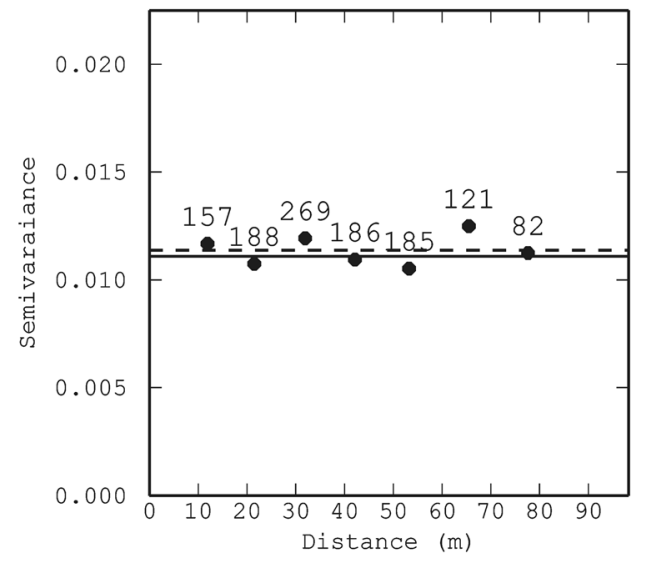

sampling periods and a moderate variability was observed. The results from the present study (Table 3 ) showed a higher variability of microbial rather than physicochemical properties (Piotrowska and Dlugosz 2012) as described by the coefficient of variation (CV\%) as well as the minimum, maximum, and standard deviation. Our results are in agreement with several studies that were carried out at the field scale on arable soils (Sebai et al. 2007; Štursová et al. 2016). In the study of Sebai et al. (2007), the microbial properties and processes were significantly influenced by properties such as organic matter content, soil moisture, $\mathrm{pH}$ values or texture. In this study, however, the variability of these properties was not a source of variability for the microbiological properties since all of them exhibited low CV values (less than 15\%) (Piotrowska and Długosz 2012).

In our conventionally managed soil, more bacterial than fungal CFUs were noted, which confirmed studies that had been done earlier (Hassink et al. 1993; Velvis 1997). Some studies have shown that soil management on arable land affects the $\mathrm{B} / \mathrm{F}$ ratio. In most cases, bacteria dominate under conventional tillage, whereas fungi dominate under notillage (de Vries et al. 2006). This has been attributed to the direct contact between bacteria and the substrate under conventional tillage, which encourages bacterial growth (Jiang et al. 2011) and could be ascribed to the suppression of fungal hyphae, and hence fungal growth, by intensive tillage (de Vries et al. 2006).

The soil microbial biomass and activity usually shows strong seasonal variation, although the trends in this variation are differentiated due to many various climatic (temperature, moisture), environmental, and anthropogenic factors that influence soil microbial communities across wide geographical regions (Gourmelon et al. 2016). Therefore, the data for the seasonal changes of soil microorganisms that is found in the literature are contradictory (e.g., Baldrian et al. 2010b), suggesting that both bacteria and fungi react to various seasonal natural and anthropogenic factors in different ways. We found significantly higher fungal CFUs in August than in April and an opposite trend for bacterial community, which could be explained by a higher temperature and soil moisture, since fungi are more sensitive to changes in climatic condition than bacteria (Kaisermann et al. 2015). In this study, a higher air temperature in August than in April (about $10^{\circ} \mathrm{C}$, Table 1) may also reflect the higher soil temperature. This could have an impact on the soil microbial properties as was stated earlier by Khalid (2012). Additionally, the nitrogen fertilizer applied 


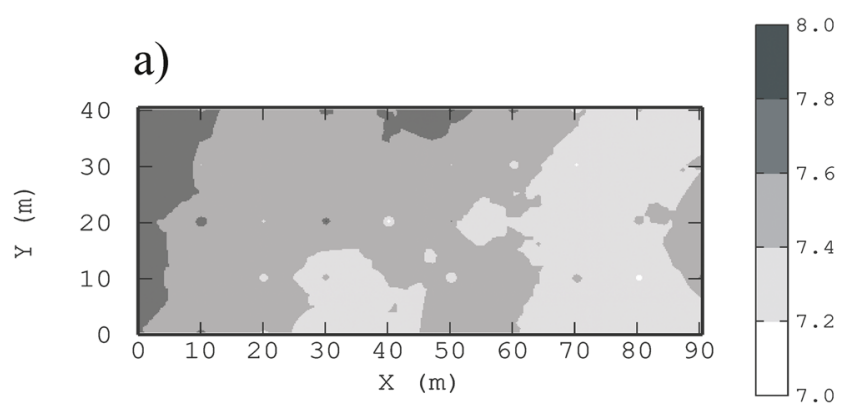

b)
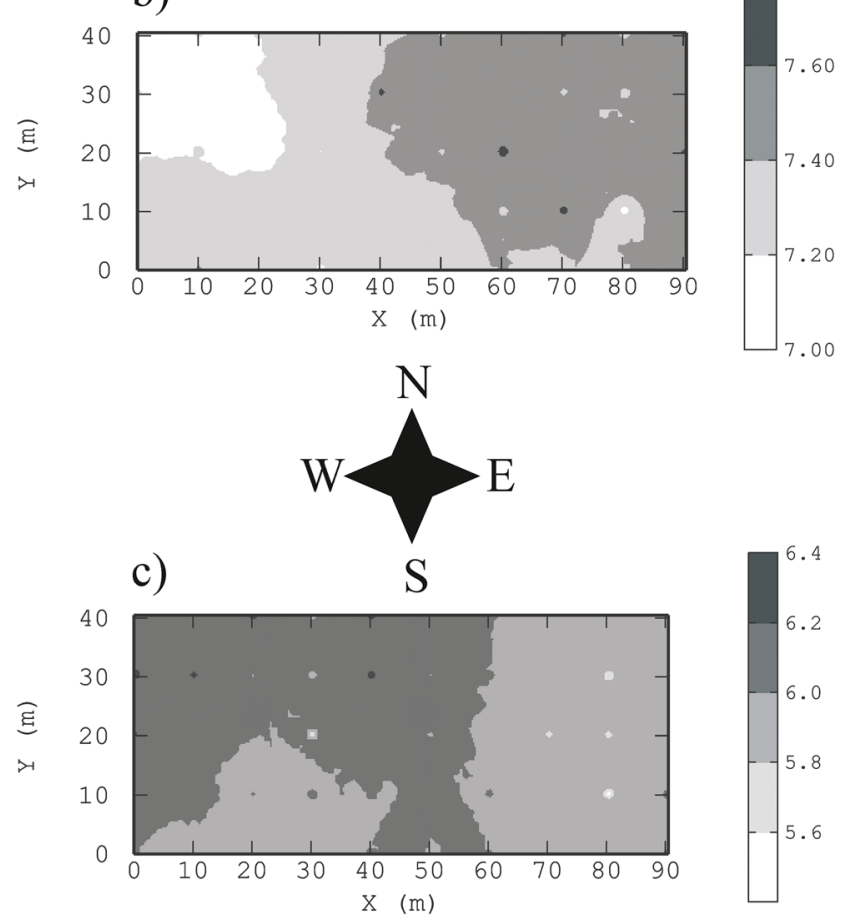

d)

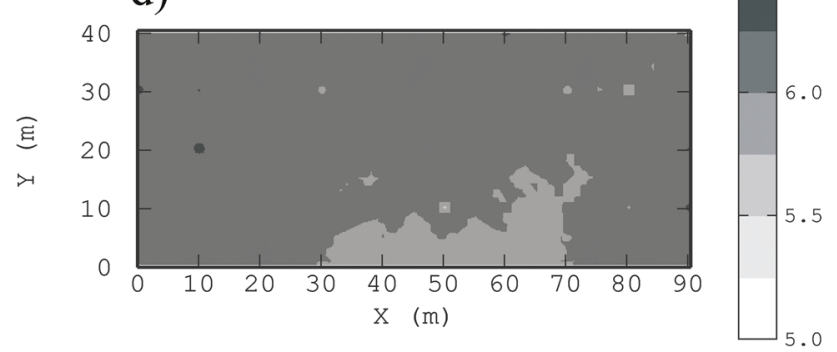

Fig. 2 Spatial distribution of (a) bacterial CFUs in April, (b) bacterial CFUs in August, (c) actinomycetes CFUs in April, (d) actinomycetes CFUs in August. In each figure, darker shading represents the highest values while light shading represents the lowest values

in spring (March) could have stimulated the bacterial community and decreased the fungi, which is partially in line with de Vries et al. (2006), who noted that an increasing $\mathrm{N}$ input in a grassland caused a decrease of the fungi biomass, while the bacterial biomass remained constant. The lack of significant differences in the actinomycetes CFUs between April and
August may be due to the fact that this community has been shown to be less sensitive to stressful conditions than either bacteria or fungi (Pourreza et al. 2014).

\subsection{Spatial variability of microbial properties}

Most of the properties studied did not exhibit spatial structure at the examined scale, thus suggesting that changes in these properties would be probably detectable at a distance shorter than $10 \mathrm{~m}$. This was confirmed by the lack of an autocorrelation and a high or pure nugget, which represents the measurement error or non-measurable variation at distances other than those sampled (Mummey et al. 2010) and is used to calculate the nugget/sill ratio, which indicates the spatial structure at the sampling scale and allows the relative size of the nugget effect among different soil properties to be compared (Webser and Oliver 2008). The absence of spatial structure or weak spatial dependence that was obtained for most of the microbial properties in this study was probably due to several different effects of (1) the content of clay, silt, and sand, which also was not spatially structured (pure nugget effect) (Piotrowska and Długosz 2012); (2) the nested occurrence of microorganisms; (3) soil structure, e.g., different type, quantity, and shape of soil aggregates; and (4) measurement error. In fact, it has been stated earlier that a weak spatial dependence of a soil property (high variability) is controlled by exogenous factors such as climatic factors (moisture and temperature) vegetation cover, or human activity and is related to experimental error (Cambardella et al. 1994; Webser and Oliver 2008). Some authors have suggested that soil microorganisms are particularly variable compared to other properties, and that their abundance and activity change along an environmental gradient (Franklin and Mills 2003; Philippot et al. 2009). Even within a homogenous system, biological processes may produce aggregations of organisms at various spatial scales (Franklin and Mills 2003). The level of spatial variability of microbial communities varied in different ranges and is related to various biotic and abiotic factors (e.g., temperature, $\mathrm{pH}$, $\mathrm{C}_{\mathrm{ORG}}$ content, and substrate availability) (Guox et al. 2012). In fact, soil properties do not vary independently and rather variably measured at a certain point in space in the outcome of several physical, chemical, and biological processes, all of which are more or less spatially variable (Guox et al. 2012). In this study, however, soil $\mathrm{pH}$ and $\mathrm{C}_{\mathrm{ORG}}$ content could not be the source of variability for soil microbial properties since they revealed strong and moderate spatial dependence (Piotrowska-Długosz et al. 2016). Based on the earlier studies, we suppose that high contribution of nugget effect in sill or pure nugget effect in this study may be partially related to the applied tillage and fertilizers that was applied in autumn in the previous year. In fact, the weak spatial dependence of soil properties or a pure nugget effect indicates an extrinsic variability, i.e., due to management practices such as tillage, 
mineral and organic fertilization, and pesticide application, (Nayak et al. 2007; García-Ruiz et al. 2008) or it is the result of an inappropriate sampling scheme.

\subsection{Correlations among the properties studied}

Previous studies have shown that the size and activity of soil microbial communities are sensitive to variations in the soil physical and chemical properties (Aciego Pietri and Brookes 2009), mainly to soil moisture, soil reaction, and organic carbon content. Some authors indicated contrasting soil $\mathrm{pH}$ effects on fungal and bacterial growth (Rousk et al. 2009), what is in agreement with our data (Table 4). In this study, we found a significant positive relationship between $\mathrm{pH}$ and the bacterial colony-forming units, while negative relationship between $\mathrm{pH}$ and fungal CFUs, for which the values of the relationship were however low (Table 4). It is possible that the small $\mathrm{pH}$ gradient (2 units) (Piotrowska and Dlugosz 2012) did not alter strongly the spatial distribution of microorganisms in soil, which was confirmed by other studies (Drenovsky et al. 2010), and did not reveal the negative relationship between bacterial and fungal CFUs. Several recent studies have shown however that soil $\mathrm{pH}$ is a strong driver of the abundance of microbial communities (Hallin et al. 2009; Kaiser et al. 2016). Thus, Bru et al. (2011) reported that soil $\mathrm{pH}$ alone explained 17.1 and $21.4 \%$ of the spatial variability in the abundance of the total bacterial community and the functional microbial community that are involved in N-cycling, respectively.

The content of $\mathrm{C}_{\mathrm{ORG}}$ was significantly correlated with the rate of soil respiration and fungal colony-forming units, although values of the correlation coefficients were low as was in the case with the soil reaction. Other studies indicated a closer relationship between $\mathrm{C}_{\mathrm{ORG}}$ content and microbial properties and showed the importance of $\mathrm{C}_{\mathrm{ORG}}$ as a microbial substrate and as a habitat for microbial growth and maintenance (Wallenius et al. 2011; Garcia-Orenes et al. 2013).

\section{Conclusions}

Most of the microbiological properties did not exhibit spatial structure at the examined scale, thus suggesting that changes in these properties would probably be detectable at a distance shorter than the one used in the study. Therefore, an evaluation of their spatial characteristics would require a higher density of sampling. Only some of the microbial properties, such as bacterial CFUs in August, actinomycetes CFUs in , and $q \mathrm{CO}_{2}$ ratio on both sampling dates, were spatially dependent at the scale of sampling grid, whereas they reveal a high variability. The spatial structure of most the variables that showed a spatial autocorrelation differed depending on the sampling time. A variation in time has affected the spatial variability and consequently has changed the shape of the semivariograms of these variables. That is why more frequent seasonal sampling should be included in the further experimental planning in order to find a suitable sampling distance for characterizing the spatial structure of properties being studied.

Acknowledgments Much gratitude is due to Michele Simmons for proof reading the article.

Funding information The research was financially supported by the Polish Ministry of Science and Higher Education (project no. N 310 $03032 / 1588$ ).

Open Access This article is distributed under the terms of the Creative Commons Attribution 4.0 International License (http:// creativecommons.org/licenses/by/4.0/), which permits unrestricted use, distribution, and reproduction in any medium, provided you give appropriate credit to the original author(s) and the source, provide a link to the Creative Commons license, and indicate if changes were made.

\section{References}

Aciego Pietri J, Brookes P (2009) Substrate inputs and pH as factors controlling microbial biomass, activity and community structure in an arable soil. Soil Biol Biochem 41:1396-1405

Anderson T, Domsch KH (1990) Application of eco-physiological quotients $(q \mathrm{CO} 2$ and $q \mathrm{D})$ on microbial biomasses from soils of different cropping histories. Soil Biol Biochem 22:251-255

Atlas RM (1997) Handbook of microbiological media. CRC Press, Boca Raton

Baldrian P, Merhautová V, Cajthaml T, Petránková M, Šnajdar J (2010a) Small-scale disturbance of extracellular enzymes, fungal, and bacterial biomass in Quercus petraea forest topsoil. Biol Fertil Soils 46: $717-726$

Baldrian P, Merhautová V, Petránková M, Cajthaml T, Šnajdar J (2010b) Distribution of microbial biomass and activity of extracellular enzymes in a hardwood forest soil reflect soil moisture content. Appl Soil Ecol 46:177-182

Bao X, Zhu X, Chang X, Wang S, Xu B, Luo C, Zhang Z, Wang Q, Rui Y, Cui X (2016) Efects of soil temperature and moisture on soil respiration on the Tibetan Plateau. PLoS One 11(10):e0165212

Bishop TFA, Lark RM (2006) The geostatistical analysis of experiments at the landscape-scale. Geoderma 133:87-106

Borowik A, Wyszkowska J (2016) Soil moisture as a factor affecting the microbiological and biochemical activity in soil. Plant Soil Environ 62(6):250-255

Bru D, Ramette A, Saby NPA, Dequiedt S, Ranjard L, Jolivet C, Arrouays D, Philippot L (2011) Determination of the distribution of nitrogen-cycling microbial communities at the landscape scale. ISME J 5:532-542

Cambardella CA, Moorman TB, Novak JM, Parkin TB, Karlen DL, Turco RF, Konopka AE (1994) Field-scale variability of soil properties in Central Iowa soils. Soil Sci Soc Am 58:1501-1511

Cavigelli MA, Lengnick LL, Buyer JS, Fravel D, Handoo Z, McCarty G, Millner P, Sikora L, Wright S, Vinyard B, Rabenhorst M (2005) Landscape level variation in soil resources and microbial properties in a no-till corn field. Appl Soil Ecol 29:99-123

Černohlávková J (2009) Effects of selected environmental pollutants on soil microbial community in laboratory and field studies. Dissertation Thesis, RECETOX - Research Centre for Environmental Chemistry and Ecotoxicology, Brno, Czech Republic 
Cobo JG, Dercon G, Yekeye T, Chapungu L, Kadzere C, Murwira A, Delve R, Cadisch G (2010) Integration of mid-infrared spectroscopy and geostatistics in the assessment of soil spatial variability at landscape level. Geoderma 158:398-411

de Vries FT, Hoffland E, von Eekeren N, Brussaard L, Bloem J (2006) Fungal/bacterial ratios in grassland with contrasting nitrogen management. Soil Biol Biochem 38:2092-2103

Deblauwe V, Kennel P, Couteron P (2012) Testing pairwise association between spatially autocorrelated variables: a new approach using surrogate lattice data. PLoS One 7(11):e48766

DeBruyn JM, Nixon LT, Fawaz MN, Johnson AM, Radosevich M (2011) Global biogeography and quantitative seasonal dynamics of Gemmatimonadetes in soil. Appl Environ Microbiol 77:6295-6300

Drenovsky RE, Steenwerth KKL, Jackson LE, Scow KM (2010) Land use and climatic factors structure regional patterns in soil microbial communities. Glob Ecol Biogeogr 19:27-39

Du Z, Riveros-Iregui DA, Jones RT, McDermott TR, Dore JE, McGlynn BL, Emanuel RE, Li X (2015) Landscape position influences microbial composition and function via redistribution of soil water across a watershed. Appl Environ Microbiol 81(24):8457-8468

Francioli D, Ascher J, Ceccherini MT, Pietramellara G (2014) Land use and seasonal effects on a Mediterranean soil bacterial community. J Soil Sci Plant Nutr 14(3):710-722

Franklin RB, Mills AL (2003) Multi-scale variation in spatial heterogeneity for microbial community structure in an eastern Virginia agricultural field. FEMS Microbial Ecol 44:335-346

Franklin RB, Mills AL (2009) Importance of spatially structured environmental heterogeneity in controlling microbial community composition at small spatial scales in an agricultural field. Soil Biol Biochem 41:1833-1840

Gangneux C, Akpa-Vincelas M, Sauvage H, Desaire S, Houot S, Laval K (2011) Fungal, bacterial and plant dsDNA contributions to soil total DNA extracted from silty soils under different farming practices: relationships with chloroform-labile carbon. Soil Biol Biochem 43: 431-437

García -Ruiz R, Ochoa V, Hinojosa B, Carreira JA (2008) Sustainability of enzyme activities for the monitoring of soil quality improvement in organic agricultural systems. Soil Biol Biochem 40:2137-2145

Garcia-Orenes F, Morugán-Coronado A, Zarnoza R, Scow K (2013) Changes in soil microbial community structure influenced by agricultural management practices in a Mediterranean agro-ecosystem. PLoS One 8(11):e80522

Gourmelon V, Maggia L, Powell JR, Gigante S, Hortal S, Gueunier C, Letellier K, Carriconde F (2016) Environmental and geographical factors structure soil microbial diversity in New Caledonian ultramafic substrates: a metagenomic approach. PLoS One 11(12): e0167405. https://doi.org/10.1371/journal.pone.0167405

Griffith DA, Chun Y (2016) Spatial autocorrelation and uncertainty associated with remotely sensed data. Remote Sens 8:535

Gülser C, Ekberli I, Candemir F, Demir Z (2016) Spatial variability of soil physical properties in a cultivated field. Eur J Soil Sci 5(3):192-200

Guox X, Amiaud B, Piutti S, Philippot L, Benizri E (2012) Spatial distribution of the abundance and activity of the sulfate esterhydrolyzing microbial community in a rape field. J Soils Sediments 12:1360-1370

Hallin S, Jones CM, Schloter M, Philippot L (2009) Relationship between $\mathrm{N}$-cycling communities and ecosystem functioning in a 50-year-old fertilization experiment. ISME J 3:597-605

Hassink J, Bouwman LA, Zwart KB, Brussaard L (1993) Relationships between habitable pore space, soil biota and mineralization rates in grassland soils. Soil Biol Biochem 25:47-55

ISO 10381-2:2002 (2002) Soil quality sampling — part 2. guidance on sampling techniques

IUSS Working Group WRB (2007) World reference base for soil resources 2006 - first update 2007. World soil resources reports no. 103. FAO, Rome
Jafari M, Asgari HM, Tahmoures T, Biniaz M (2011) Assessment of soil property spatial variation based on the geostatistical simulation. Desert 16:87-101

Jiang X, Wright AL, Wang X, Linag F (2011) Tillage-induced changes in fungal and bacterial biomass associated with soil aggregates: a longterm field study in a subtropical rice soil in China. Appl Soil Ecol 48: $186-173$

Kaiser K, Wemheuer B, Korolkow V, Wemheuer F, Nacke H, Schöning I, Schrumpf M, Daniel R (2016) Driving forces of soil bacterial community structure, diversity, and function in temperate grasslands and forests. Sci Rep 6:33696

Kaisermann A, Maron PA, Beaumelle L, Lata JC (2015) Fungal communities are more sensitive indicators to non-extreme soil moisture variations than bacterial communities. Appl Soil Ecol 86:158-164

Kennedy N, Brodie E, Connolly J, Clipson N (2006) Seasonal influences on fungal community structure in unimproved and improved upland grassland soils. Can J Microbiol 52:689-694

Kerry R, Oliver MA (2007) Comparing sampling needs for variograms of soil properties computed by the method of moments and residual maximum likelihood. Geoderma 140:383-396

Khalid KA (2012) Biological fertilization and its effect on medicinal and aromatic plants. Bioscience 4(3):124-133

Lauber C, Ramirez KS, Aanderud Z, Lennon J, Fierer N (2013) Temporal variability in soil microbial communities across land-use types. ISME J 7(8):1641-1650

Lipson DA (2007) Relationships between temperature responses and bacterial community structure along seasonal and altitudinal gradients. FEMS Microbiol Ecol 59:418-427

Liu X, Zhang W, Zhang M, Ficklin DL, Wang F (2009) Spatio-temporal variation of soil nutrients influenced by an altered land tenure system in China. Geoderma 152:23-43

Liu Q, Xie WJ, Xia JB (2013) Using Semivariogram and Moran's I Techniques to evaluate spatial distribution of soil micronutrients. Commun Soil Sci Plant Anal 44(7):1182-1192

Martiny JBH, Eisen JA, Penn K, Allison SD, Horner-Devine MC (2011) Drivers of bacterial of bacterial beta-diversity depend on spatial scale. Proc Natl Acad Sci U S A 108:7850-7854

Mummey DL, Clarke JT, Cole CA, O'Connor G, Gannon JE, Ramsey PW (2010) Spatial analysis reveals differences in soil microbial community interactions between adjacent coniferous forest and clear cut ecosystems. Soil Biol Biochem 42:1138-1147

Nayak DR, Babu YJ, Adhya TK (2007) Long-term application of compost influences microbial biomass and enzyme activities in a tropical Aeric Endoaquept planted to rice under flooded condition. Soil Biol Biochem 39:1897-1906

Nunan N, Wu K, Young IM, Crawford JW, Ritz K (2003) Spatial distribution of bacterial communities and their relationship with the micro-architecture of soil. FEMS Microbial Ecol 44:203-215

Pandey RR, Sharma G, Tripathi SK, Singh AK (2007) Litterfall, litter decomposition and nutrient dynamics in a subtropical natural oak forest and managed plantation in northeastern India. For Ecol Manag 240:96-104

Peigné J, Vian JF, Cannavacciuolo M, Bottollier B, Chaussod R (2009) Soil sampling based on field spatial variability of soil microbial indicators. Eur J Soil Biol 45:488-495

Philippot L, Čuhel J, Saby NPA, Chèneby D, Chroňáková A, Bru D, Arrouays D, Martin-Laurent F, Šimek M (2009) Mapping field scale spatial patterns of size and activity of denitrifier community. Environ Microbiol 11:1518-1526

Piotrowska A, Długosz J (2012) Spatio-temporal variability of microbial biomass content and activities related to some physicochemical properties of Luvisols. Geoderma 173-174:199-208

Piotrowska A, Iamarino G, Rao MA, Gianfreda L (2006) Short-term effects of olive mill wastewater (OMW) on chemical and biochemical properties of a semiarid Mediterranean soil. Soil Biol Biochem 38:600-610 
Piotrowska-Długosz A, Lemanowicz J, Długosz J, Spychaj-Fabisiak E, Gozdowski D, Rybacki M (2016) Spatio-temporal variation of soil properties in a plot scale: a case study of soil phosphorus and related enzymes. J Soils Sediments 16:62-76

Piotrowska-Długosz A, Siwik-Ziomek A, Długosz J, Gozdowski D (2017) Spatio-temporal variability of soil sulfur content and arylsulfatase activity at a conventionally managed arable field. Geoderma 295:107-118

Pourreza M, Hosseini SM, Safari Sinegani AA, Matinizadeh M, Dick WA (2014) Soil microbial activity in response to fire severity in Zagros oak (quercus brantii Lindl.) forest, Iran, after one year. Geoderma 213:95-102

Rasche F, Knapp D, Kaiser C, Koranda M, Kitzler B, ZechmeisterBoltenstern S, Richter A, Sessitsch A (2011) Seasonality and resource availability control bacterial and archaeal communities in soils of a temperate beech forest. ISME J 5:389-402

Rousk J, Brooks PC, Bååth E (2009) Contrasting soil pH effects on fungal and bacteria growth suggest functional redundancy in carbon mineralization. Appl Environ Microbiol 75(6):1589-1598

Sebai T, Lagacherie B, Soulas G, Martin-Laurent F (2007) Spatial variability of isoproturon mineralizing activity within an agricultural field: Geostatistical analysis of simple physicochemical and microbiological soil parameters. Environ Pollut 145:680-690

Shahandeh H, Wright AL, Hons FM (2005) Spatial and temporal variation of soil nitrogen parameters related to soil texture and corn yield. Agron J 97:772-782

Stotzky G (1965) Microbial respiration. In: Black CA (ed) Methods of soil analysis. American Society of Agronomy, Madison

Štursová M, Bárta J, Šantrůčková H, Baldrian P (2016) Small-scale spatial heterogeneity of ecosystem properties, microbial community composition and microbial activities on a temperate mountain forest soil. FEMS Microbial Ecol 92(12):fiw 185

Tecon R, Or D (2017) Biophysical processes supporting the diversity of microbial life in soil. FEMS Microbial Rev 41(5):599-623

Velvis H (1997) Evaluation of the selective respiratory inhibition method for measuring the ratio of fungal: bacterial activity in acid agricultural soils. Biol Fertil Soils 25:354-360

Wallenius K, Rita H, Mikkonen A, Lappi K, Lindström K, Hartikainen H, Raateland A, Niemi R (2011) Effects of land use on the level, variation and spatial structure of soil enzyme activities and bacterial communities. Soil Biol Biochem 43:1464-1473

Wang HJ, Shi XZ, Yu DS, Weindorf DC, Huang B, Sun WX, Ritsema CJ, Milne E (2009) Factors determining soil nutrient distribution in a small-scaled watershed in the purple soil region of Sichuan Province, China. Soil Tillage Res 105:300-306

Wardle DA (1998) Controls of temporal variability of the soil microbial biomass: a global-scale synthesis. Soil Biol Biochem 30:1627-1637

Webser R, Oliver M (2008) Geostatistics for environmental sciences. Wiley and Sons, Ltd

Wilding LP (1985) Spatial variability: its documentation, accommodation, and implication to soil surveys. In: Nielsen DR, Bouma J (eds) Soil spatial variability. Pudoc, Wageningen

Yergeau E, Bezemer TM, Hedlund K, Mortimer SR, Kowalchuk GA, van der Putten WH (2010) Influences of space, soil, nematodes and plants on microbial community composition of chalk grassland soils. Environ Microbiol 12:2096-2106

Zhang NL, Xia JY, Yu XJ, Ma KP, Wan SQ (2011) Soil microbial community changes and their linkages with ecosystem carbon exchange under asymmetrically diurnal warming. Soil Biol Biochem 43: 2053-2059 